\title{
PENINGKATKAN HASIL BELAJAR SISWA MELALUI METODE INKUIRI MATA PELAJARAN PKn KELAS IV SD NEGERI 164519 KOTA TEBING TINGGI
}

\author{
Syarigfah \\ Guru SD Negeri 164519 Kota Tebing Tinggi \\ Surel : syarigfah16@gmail.com
}

\begin{abstract}
ABSTRAK
Penelitian ini bertujuan untuk meningkatkan hasil belajar siswa mata pelajaran PKn melaui metode pembelajaran inquiry. Penelitian tindakan kelas ini dilaksanakan sebanyak 3 siklus dengan empat tahapan yaitu : perencanaan, pelaksanaan, observasi, refleksi. Subjek penelitian ini adalah siswa kelas IV SDN 164519 Tebing Tinggi sebanyak 33 siswa. Penelitian ini menggunakan teknik analisis dekriptif kualitatif. Hasil penelitian menunjukkan bahwa penggunaan metode Inquiry mata pelajaran PKn dapat meningkatkan hasil belajar siswa yang ditandai dengan peningkatan ketuntasan belajar siswa, yaitu pra siklus (51,51\%), siklus I (57,57 \%), siklus II $(81,81 \%)$, siklus III $(90,90 \%)$ dan dinyatakan berhasil secara klasikal $90,90 \%$.
\end{abstract}

Kata Kunci : Inkuiri, Hasil belajar, PKn

\section{PENDAHULUAN}

Perkembangan

IPTEK

sekarang ini membawa perubahan gaya hidup manusia baik dalam bidang sosial, sains, teknologi, budaya, informasi maupun pendidikan. Hal ini merupakan tantangan dan kesempatan untuk dapat meningkatkan mutu sumber daya manusia agar dapat bersaing dalam dunia yang penuh dengan persaingan hidup.

Peningkatan mutu pendidikan diarahkan untuk meningkatkan kualitas manusia seutuhnya melalui olah pikir olah hati dan olah rasa agar memiliki daya saing dalam menghadapi tantangan global. Belajar diartikan sebagai proses perubahan tingkah laku pada diri materi yang dipelajari oleh siswa dapat dipahami dengan baik serta individu berkat adanya interaksi antara individu dengan lingkungannya (Usman, $2000: 5$ ).

Proses belajar mengajar
adalah suatu kegiatan yang
didalamnya terjadi proses siswa
belajar dan guru mengajar dalam
konteks interaktif, dan terjadilah interaksi edukatif antara guru dan siswa (Hamalik, 2001:48). Guru sebagai salah satu komponen dalam proses belajar mengajar memegang peranan yang sangat penting. Peran guru tidak hanya menyampaikan materi saja melainkan sebagai pengendali serta pelaku dalam kegiatan proses belajar mengajar.

Seorang guru harus dapat memilih dan menerapkan model pembelajaran yang efektif agar dapat meningkatkan hasil belajar. Menurut A.Ubaedillah dan Abdul 
Rozak (2008 : 4), Pendidikan kewarganegaraan dijadikan sebagai wadah dan instrumen untuk mewujudkan tujuan pendidikan nasional, yaitu "berkembangnya potensi peserta didik agar menjadi manusia yang beriman dan taqwa kepada Tuhan Yang Maha Esa, berakhlak mulia, sehat, berilmu, cakap, kreatif, mandiri dan menjadi warga negara yang demokratis serta bertanggung jawab".

Dalam proses pembelajaran PKn, kegiatan siswa masih kurang diperhatikan, siswa hanya diminta untuk memperhatikan penjelasan guru dan jarang sekali diminta untuk bertanya. Siswa jarang sekali diminta untuk memberikan pertanyaan atau memberikan pendapat terhadap materi pelajaran yang sedang dipelajari. Akibatnya tidak jarang ditemukan siswa yang mengganggu temannya pada saat belajar dan tertidur di dalam kelas.

Salah satu alternatif yang paling efektif dan efisien diantaranya adalah dengan melakukan penelitian tindakan kelas metode inkuiri. Peneliti memilih metode inkuiri, karena metode ini mengajak siswa untuk lebih aktif dan membangun kemampuan berpikir siswa secara individu maupun kelompok, untuk membangun pengembangan pengetahuan siswa dan hasil belajar siswa dapat meningkat.

Menurut Trianto (2007: 135). Pembelajaran inkuiri adalah suatu rangkaian kegiatan belajar yang melibatkan secara maksimal seluruh kemampuan siswa untuk mencari dan menyelidiki secara sistematis, kritis, logis, analitis, sehingga siswa dapat merumuskan sendiri penemuannya dengan penuh percaya diri.

Pembelajaran metode inkuiri menekankan pada pengembangan aspek kognitif, afektif, dan psikomotorik secara seimbang. Siswa menjadi aktif dalam mencari dan mengolah sendiri informasi. Siswa mengerti konsep-konsep dasar dan ide-ide secara lebih baik. Memberikan ruang kepada siswa untuk belajar sesuai dengan gaya belajar mereka. Siswa yang memiliki kemampuan diatas rata-rata tidak akan terhambat oleh siswa yang lemah dalam belajar. Membantu siswa dalam menggunakan ingatan dalam transfer konsep yang dimilikinya kepada situasi-situasi proses belajar yang baru. Mendorong siswa untuk berfikir intuitif dan merumuskan hipotesisnya sendiri. Dapat membentuk dan mengembangkan konsep sendiri (self-concept) pada diri siswa sehingga secara psikologis siswa lebih terbuka terhadap pengalaman baru, berkeinginan untuk selalu mengambil dan mengeksploitasi kesempatan - kesempatan yang ada (Sanjaya, 2006:206-207).

Proses pembelajaran PKn dimaknai sebagai wahana untuk pembentukan jati diri dan cinta terhadap tanah air melalui internalisasi/personalisasi nilai agama dan budaya, yang melandasi nilai-nilai sebagai berikut, yaitu: nilai kemanusiaan (human relationship), 
nilai politik, nilai ilmu pendidikan dan teknologi, nilai seni, nilai ekonomi, dan nilai kesehatan, yang merupakan kegiatan dasar manusia dalam rangka membangun wawasan warga negara menjadi lebih baik (good cityzenship), menjadi manusia seutuhnya atau berakhlaqul karimah, sehingga perspektif yang digunakan adalah aspek internal bangsa, atau perspektif ke-Indonesiaan (Aryani dan Susantim, 2010:132).

Berdasarkan permasalahan tersebut maka penulis tertarik untuk meneliti metode ini karena siswa dapat terlibat secara aktif dalam kegiatan proses pembelajaran, mengembangkan didisiplin intelektual dan keterampilan berpikir dengan memberikan pertanyaan pertanyaan dan mendapatkan jawaban atas dasar rasa ingin tahu mereka khususnya pada mata pelajaran PKn materi sistem pemerintahan desa dan kecamatan.

Tujuan dari penelitian ini adalah untuk meningkatkan hasil belajar PKn.

Berdasarkan uraian pada latar belakang masalah, maka dapat dirumuskan permasalahan sebagai berikut: "Apakah dengan menggunakan pembelajaran metode Inkuiri dapat meningkatkan hasil belajar PKn siswa kelas IV SD Negeri 164519 kota Tebing Tinggi?"

\section{METODE PENELITIAN}

Penelitian ini diawali dengan pengajuan judul tentang penelitian yang akan dilaksanakan. Subyek penelitian adalah siswa kelas IV SD
Negeri 164519 Tebing Tinggi semester I tahun 2013/ 2014 dengan jumlah siswa sebanyak 33 orang dengan 15 orang laki-laki dan 18 orang perempuan. Sumber data yang digunakan adalah siswa dan teman sejawat. Pada Penelitian tindakan kelas data yang dikumpulkan dapat berbentuk kuantitatif maupun kualitatif. Penelitian tindakan kelas tidak menggunakan uji statistik, tetapi dengan deskriptif.

Data kuantitatif yang berupa nilai dianalisis dengan menggunakan analisis deskriptif komparatif yaiu membandingkan nilai tes kondisi awal, nilai tes setelah siklus I, II dan siklus III yaitu nilai dari hasil ulangan harian siswa kelas IV SD Negeri 164519 pada siklus I, II dan siklus III. Komponen pengajaran metode inkuiri yang sangat data kualitatif yang berupa observasi kegiatan guru, dan sisa serta data kuantitatif yang berupa nilai hasil ulangan harian siswa kelas IV.

Model penelitian tindakan kelas yang digunakan peneliti adalah system spiral refleksi diri yang dikembangkan oleh Kemmis dan Taggart (1990:11) yang dimulai dengan perencanaan, tindakan, pengamatan, dan refleksi. Masingmasing siklus terdiri dari dua kali pertemuan yaitu sebagai berikut:

\section{Perencanaan}

Sebelum

mengadakan penelitian peneliti menyusun rumusan masalah, tujuan dan membuat rencana tindakan, termasuk di dalamnya RPP, LKS, instrumen 
penelitian dan perangkat pembelajaran.

\section{Pelaksanaan}

\section{a. Siklus I}

Dengan bimbingan guru, siswa membentuk kelompok secara heterogen. Guru melakukan pembelajaran di dalam kelas dengan menggunakan panduan perencanaan yang telah dibuat. Penerapan metode Inkuiri dilakukan dengan menugaskan kepada masing-masing kelompok untuk mendiskusikan materi yang dibahas. Pada saat kegiatan pembelajaran berlangsung guru sebagai peneliti dibantu oleh para observer lainnya untuk melakukan pengamatan, pendokumentasian, selain itu peneliti bertindak sebagai fasilitator, motivator dan sekaligus sebagai pengamat.

\section{b. Siklus II}

Guru

melakukan pembelajaran didalan kelas dengan menggunakan panduan perencanaan yang telah dibuat. Materi yang diajarkan guru sesuai dengan materi sistem pemerintahan desa dan kecamatan. Pada Siklus kedua ini juga, suasana pembelajaran masingmasing kelompok di lingkungan sekolah dikondisikan agar tidak terlalu formal, maksudnya siswa bebas mengemukakan pendapatnya tentang materi ajar sesuai dengan kompetensi dasar yang ingin dicapai.

\section{c. Siklus III}

Perencanaan metode inkuiri dilakukan dengan menugaskan kepada masing-masing kelompok untuk mendiskusikan materi yang diajarkan guru dengan materi sistem pemerintahan desa dan kecamatan. Pada siklus III ini, siswa sudah terbiasa dengan metode belajar inquiri sehingga siswa tidak canggung untuk berdiskusi ataupun mengajukan pertanyaan.

\section{Observasi/Pengamatan}

Pengamatan dilakukan peneliti sendiri dan dibantu oleh pengamat dan mencatat proses penerapan teknik pengajaran kolaborasi.

\section{Refleksi}

Peneliti mengkaji, melihat dan mempertimbangkan hasil atau dampak dari tindakan yang dilakukan berdasarkan lembar pengamatan yang diisi oleh pengamat. Tahapan ini dilakukan secara berkesimbungan sehingga ditemukan hasil yang optimal. Kegiatan pada tahap refleksi meliputi kegiatan menganalisis, memahami dan membuat kesimpulan berdasarkan hasil observasi setiap siklus.Menemukan kelebihan dan kelemahan tindakan perbaikan pembelajaran. Hasil analisis data yang dilaksanakan pada tahap ini akan dipergunakan untuk menemukan kelebihan dan kelemahan diri dalam merancang dan melakukan tindakan sebagai acuan. 
HASIL PENELITIAN DAN PEMBAHASAN

Hasil penelitian tindakan kelas menunjukkan bahwa pengamatan yang dilakukan oleh mitra kolaborasi dan peneliti pada aktivitas guru dan siswa melalui penerapan metode Inkuiri pada mata pelajaran PKn materi system pemerintahan desa dan kecamatan, kelas IV SD Negeri 164519 Tebing Tinggi dapat dilihat pada Tabel 1 yaitu sebagai berikut:

\section{Tabel Peningkatan Hasil Belajar Siswa Siklus I, II dan III}

\begin{tabular}{|l|c|c|c|c|}
\hline \multirow{2}{*}{ Ket } & \multicolumn{4}{|c|}{ Peningkatan Hasil Belajar } \\
\cline { 2 - 5 } & $\begin{array}{c}\text { Pra } \\
\text { siklus }\end{array}$ & $\begin{array}{c}\text { Siklus } \\
\text { I }\end{array}$ & $\begin{array}{c}\text { Siklus } \\
\text { II }\end{array}$ & $\begin{array}{c}\text { Siklus } \\
\text { III }\end{array}$ \\
\hline $\begin{array}{l}\text { Nilai } \\
\text { ulangan } \\
\text { harian }\end{array}$ & 65,43 & 70,15 & 74,69 & 76,51 \\
\hline $\begin{array}{l}\text { Jumlah } \\
\text { siswa }\end{array}$ & 17 & 19 & 27 & 30 \\
\hline $\begin{array}{l}\text { Persen } \\
\text { Ketuntasan } \\
\text { Belajar (\%) }\end{array}$ & 51,51 & 57,57 & 81,81 & 90,90 \\
\hline
\end{tabular}

Berdasarkan pengamatan peneliti dari tindakan pra siklus, siklus I, siklus II dan siklus III pada Tabel 1 terjadi peningkatan hasil belajar pada jumlah siswa dan persen ketuntasan belajar secara klasikal. Hal ini dapat dilihat dengan peningkatan jumlah siswa dari 17 siswa yang tuntas belajar pada pra siklus menjadi 30 siswa yang tuntas belajar melalui metode pembelajaran inkuiri materi sistem pemerintahan desa dan kecamatan pada siswa kelas IV SD Negeri 164519 Tebing Tinggi.
Kemampuan siswa pada pra siklus dalam memahami sistem pemerintahan di Indonesia dari tingkat desa sampai dengan tingkat pusat masih rendah. Aktivitas siswa pada prasiklus dalam mendengarkan/ memperhatikan penjelasan guru, mengerjakan tugas yang diberikan guru, keantusiasan siswa mengikuti pelajaran, menuliskan dan menyampaikan hasil percobaan, bekerja sama dan berdiskusi dengan kelompok juga masih rendah maka dari itu dilakukan penelitian siklus I.

Sebelum dilakukan metode inkuiri siswa mengalami kesulitan memahami konsep - konsep pada pembelajaran PKN. Siswa belum menunjukkan antusiasme tinggi dalam pembelajaran PKn. Rendahnya hasil belajar siswa pembelajaran PKn dipengaruhi oleh beberapa hal yaitu: siswa selalu menganggap bahwa pelajaran PKn merupakan pelajaran yang sepele karena mata pelajaran PKn tidak diujikan pada Ujian Nasional, siswa cepat merasa bosan, siswa cenderung mengahafal materi dibandingkan memahami materi tersebut sehingga tak jarang siswa cepat lupa materi yang telah diajarkan sebelumnya.

Hasil ulangan siswa pada pelajaran PKn di kelas IV masih kurang memuaskan, yaitu hanya memperoleh rata-rata 65, sedangkan Kriteria Kelulusan Minimal (KKM) yang harus dicapai siswa adalah 70 . Dari 33 orang siswa yang mengikuti ujian pada pelajaran PKn hanya 11 orang siswa atau $33,33 \%$ yang berhasil mendapatkan nilai di atas 
nilai 70 , sedangkan 22 orang siswa atau $66,67 \%$ mendapat nilai di bawah nilai 70 .

Dari Tabel 1 dapat dijelaskan bahwa dengan menerapkan metode pembelajaran inkuiri pada materi "sistem pemerintahan desa dan kecamatan" diperoleh nilai rata-rata ulangan harian siswa adalah 70,15 dan ketuntasan belajar mencapai $57,57 \%$ atau ada 19 siswa dari 33 siswa sudah tuntas belajar. Hasil tersebut menunjukkan bahwa pada siklus pertama secara klasikal siswa belum tuntas belajar, karena siswa yang memperoleh nilai $\geq 65$ hanya sebesar 57,57 \% lebih kecil dari persentase ketuntasan yang dikehendaki yaitu sebesar $85 \%$. Hal ini disebabkan karena siswa masih bingung dalam memahami konsepkonsep materi pembelajaran. Siswa masih terlihat pasif dan mengandalkan teman sekelompoknya menunggu hasil pekerjaan temannya. Oleh karena itu dilanjutkan penelitian siklus kedua untuk meningkatkan hasil belajar siswa.

Pada Tabel 1, metode pembelajaran inkuiri pada siklus II materi "sistem pemerintahan desa dan kecamatan" diperoleh nilai ratarata ulangan harian siswa adalah 74,69 dan ketuntasan belajar mencapai $81,81 \%$ atau ada 27 siswa dari 33 siswa sudah tuntas belajar. Hasil tersebut menunjukkan bahwa pada siklus pertama secara klasikal siswa belum tuntas belajar, karena siswa yang memperoleh nilai $\geq 65$ hanya sebesar $81,81 \%$ lebih kecil dari persentase ketuntasan yang dikehendaki yaitu sebesar $85 \%$.

Pada siklus II, siswa sudah dapat bekerjasama dengan teman sekelompoknya meskipun masih ada siswa yang pasif namun hal ini masih dianggap baik oleh peneliti. Siswa dapat menyelesaikan tugas dengan baik. Ada keberanian siswa untuk dapat menjawab pertanyaan yang diberikan oleh guru. Pembelajaran yang dilaksanakan telah mampu meningkatkan hasil belajar siswa meskipun belum mencapai kriteria ketuntasan belajar yang diharapkan. Oleh karena itu dilanjutkan penelitian siklus ketiga untuk meningkatkan hasil belajar siswa.

Dari tabel 1 dapat dilihat bahwa dengan menerapkan metode pembelajaran inkuiri pada materi "sistem pemerintahan desa dan kecamatan" diperoleh nilai rata-rata ulangan harian siswa adalah 76.51 dan ketuntasan belajar mencapai $90.90 \%$ atau ada 30 siswa dari 33 siswa sudah tuntas belajar. Hasil tersebut menunjukkan bahwa pada siklus ketiga secara klasikal siswa sudah tuntas belajar, karena siswa yang memperoleh nilai $\geq 65$ sebesar $90.90 \%$. Nilai tersebut sudah melebihi dari persentase ketuntasan yang dikehendaki yaitu sebesar $85 \%$.

Siswa dapat memahami konsep-konsep materi pembelajaran yaitu dengan mengetahui sistem pemerintahan desa dan kecamatan. Selain itu, siswa memiliki keberanian untuk dapat menjawab pertanyaan yang diberikan oleh guru. Hasil belajar siswa ini digunakan untuk 
mengetahui sejauh mana pemahaman siswa terhadap materi pembelajaran yang telah disampaikan.

Selain itu peran guru juga mempengaruhi hasil belajar siswa. Seorang guru seharusnya mampu merangsang daya pikir dan kreatifitas peserta didik dalam menemukan informasi. Guru harus mampu menciptakan suatu lingkungan belajar yang kondusif dan memahami kesulitan yang dihadapi siswa ketika pembelajaran berlangsung. Guru harus menghindari penyajian informasi dalam bentuk ceramah karena hal ini akan mengakibatkan kurangnya partisipasi siswa dalam kegiatan pembelajaran untuk memenuhi salah satu karakteristik model yang diharapkan siswa menjadi aktif dalam mencari dan mengolah sendiri informasi.

Dari hasil tes ini dapat dilihat bahwa hasil belajar dengan menggunakan pembelajaran inkuiri telah mampu meningkatkan pemahaman siswa mengenai materi pelajaran PKn sesuai dengan indikator yang telah ditentukan sehingga tidak perlu lagi dilanjutkan pada siklus berikutnya dan dikatakan berhasil. Gambaran peningkatan ketuntasan belajar yang diperoleh setelah melakukan penelitian dengan menggunakan metode inkuiri terlihat pada diagram berikut:
Diagram Peningkatan

Ketuntasan Belajar

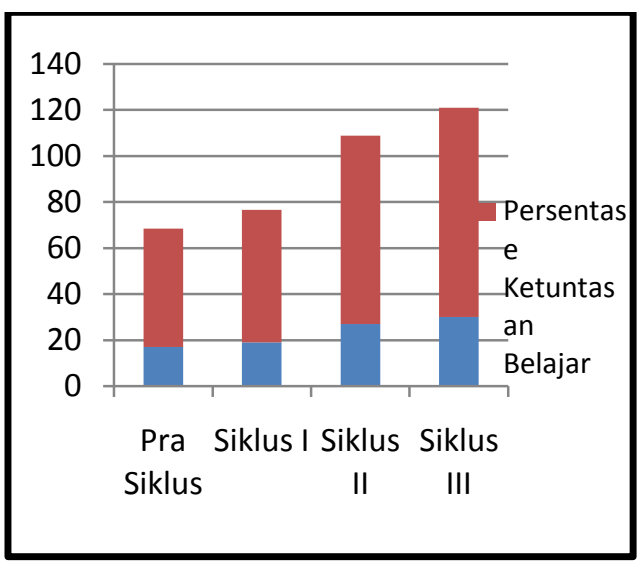

Penggunaan metode Inkuiri membuat siswa mengerti konsepkonsep dasar dan ide - ide secara lebih baik, memberikan ruang kepada siswa untuk belajar sesuai dengan gaya belajar mereka, siswa yang memiliki kemampuan diatas rata - rata tidak akan terhambat oleh siswa yang lemah dalam belajar, mendorong siswa untuk berfikir intuitif dan merumuskan hipotesisnya sendiri, dapat membentuk dan mengembangkan konsep sendiri (self-concept) pada diri siswa sehingga secara psikologis siswa lebih terbuka terhadap pengalaman baru (Sanjaya, 2006 : 206-207).

Berdasarkan hasil yang didapat dari setiap siklus proses pembelajaran yang optimal, hal ini ditunjukkan dengan meningkatnya penguasaan materi dan hasil belajar siswa. Oleh karena itu dapat disimpulkan bahwa proses pembelajaran dengan penerapan inkuiris sangat sesuai dengan mata pelajaran PKn. Maka Penelitian 
Tindakan Kelas (PTK) ini bisa dikatakan berhasil karena hasil peningkatan proses pembelajarannya optimal.

\section{KESIMPULAN}

Dari hasil temuan penelitian tentang hasil belajar siswa dengan metode eksperimen di kelas IV SD Negeri 164519 Tebing Tinggi tahun pelajaran 2013/2014 berdampak positif dalam meningkatkan hasil belajar siswa. Hal tersebut dapat dilihat dari peningkatan persentase ketuntasan belajar siswa pada pra siklus $(51,51 \%)$, siklus I $(57,57 \%)$, siklus II $(81,81 \%)$, dan siklus III $(90,90 \%)$.

Atas dasar simpulan dan implikasi hasil penelitian tindakan kelas di atas, penulis memberikan saran-saran sebagai berikut :

a. Bagi Sekolah

Sebaiknya menyediakan sarana yang dapat mendukung kegiatan belajar mengajar dan memperbanyak sarana pendukung dalam kegiatan belajar mengajar.

b. Bagi Guru

Perangkat pembelajaran dengan pendekatan inkuiri hendaknya dikembangkan untuk pokok bahasan PKn yang lain pendekatan inkuiri.

c. Bagi Siswa

Siswa diharapkan untuk turut berperan aktif dalam proses pembelajaran di kelas.

\section{DAFTAR RUJUKAN}

A.Ubaedilla dkk,. 2008. Civic Education. Jakarta: UIN Syarif Hidayatullah.

Aryani, Ine Kusuma dan Susantim, Markum. 2010. Pendidikan

Kewarganegaraan Berbasis

Nilai. Bogor: Ghalia Indonesia.

Hamalik, O. 2001.Proses Belajar Mengajar. Bandung: Bumi Aksara.

Sanjaya, W. 2006. Strategi

Pembelajaran Berorientasi

Standar Proses Pendidikan.

Jakarta: Kencana.

Trianto. 2007. Model-model

Pembelajaran Inovatif

Berorientasi

Konstruktivistik. Jakarta:

Prestasi Pustaka.

Usman, Uzer. 2000. Menjadi Guru Profesional. Bandung: PT. Remaja Rosdakarya. 